American Journal of Biochemistry and Biotechnology 4 (2): 101-104, 2008

ISSN 1553-3468

(C) 2008 Science Publications

\title{
Red-Cell Trace Minerals in Children with Autism
}

\author{
Joan Jory and Woody R. McGinnis \\ Suite 218, Stone Road Mall, 435 Stone Road West, Guelph, Ontario, N1G 2X6, Canada
}

\begin{abstract}
Abnormalities in mineral-dependent antioxidant enzymes in children with autism raise interest in the determination of trace mineral status in this population. A cross sectional investigation of red cell mineral levels was carried out among 20 children with autism and 15 controls. Children with autism demonstrated significantly lower red cell selenium $(\mathrm{p}<0.0006)$ and higher molybdenum $(\mathrm{p}<0.01)$ than the controls. There was a trend toward lower red cell zinc and higher cobalt and vanadium, among the children with autism. There were no differences in red cell levels of chromium, copper, manganese, or magnesium. These findings confirm an earlier report of low red cell selenium in autism and support a role for decreased trace mineral status in oxidative stress in autism through alteration of selenium-dependent antioxidant enzymes and increased lipid peroxidation.
\end{abstract}

Key words: Oxidative stress selenium zinc

\section{INTRODUCTION}

Although lower dietary intakes of trace minerals are reported in children with autism ${ }^{[1]}$, little is known about concentrations of trace minerals in blood. Redcell mineral analysis provides an enhanced diagnostic tool for the assessment of childhood mineral status. This study sought to measure red-cell trace minerals in children with autism compared to age-matched controls.

Specific biochemical abnormalities in children with autism particularly heighten interest in selenium and zinc status. Increased lipid peroxidation ${ }^{[2]}$ and decreased glutathione peroxidase (GSHPx) in red-cells of children with autism ${ }^{[3,4]}$ suggest possible deficiency of selenium, borderline status of which is associated with reduced GSHPx activity.

Superoxide dismutase (SOD), another important anti-oxidant enzyme, is zinc-dependent. Red-cell SOD activity is depressed in children with autism ${ }^{[4]}$ and marginal deficiency of zinc in humans is associated with lower SOD activity ${ }^{[5]}$. A retrospective study reported subnormal plasma zinc concentrations in forty percent of children with autism ${ }^{[6]}$.

\section{MATERIALS AND METHODS}

Study participants: The participants in the study included 20 children with a recent prior diagnosis of autism (age: $3.90 \pm 1.68 ; 4$ female, 16 male) and 15

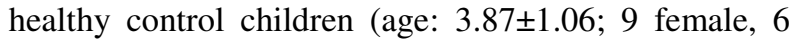

male). Developmental pediatricians and psychologists in the various regions of participant residence in accordance with DSM-IV criteria carried out diagnosis of autism. Inclusion criteria for the study required verbal parental confirmation of diagnosis. Hard copy confirmation of diagnosis was not collected.

Additional study criteria included a history of no specialty diets (gluten-free/casein-free), no regular nutritional supplements or pharmaceutical medication intake and no recent illness for the two weeks prior to blood collection.

Study design: This study was designed as a one-time cross-sectional comparison of red-cell concentrations of trace elements to assess potential differences between children with autism and healthy controls of the same age. A five day food diary was requested for all participants. However, compliance and quality of record keeping were too poor to provide reliable comparative data. Human ethics approval was carried out by IRB Institutional Review Board Services, Aurora, Ontario, Canada.

Sample collection and treatment: Morning fasting blood samples were collected in lithium-heparin traceelement free evacuated tubes. The samples were centrifuged at 24000 for 10 minutes. White cells and plasma were removed from the samples. Red cells were transferred by trace element-free pipette to trace element-free travel tubes and held at room temperature pending transportation by overnight courier to the

Corresponding Author: Joan Jory, MSc, PhD, RD. Suite 218, Stone Road Mall, 435 Stone Road West, Guelph, Ontario, N1G 2X6, Canada 
Am. J. Biochem. \& Biotech., 4 (2): 101-104, 2008

Table 1: Red blood cell trace elements

\begin{tabular}{|c|c|c|c|}
\hline & $\begin{array}{l}\text { Autistic Children }(\mathrm{n}=20) \\
(4 \text { Female,16 Male }) \\
\text { Mean }( \pm \text { SD })\end{array}$ & $\begin{array}{l}\text { Control Children }(\mathrm{n}=15) \\
(9 \text { Female, } 6 \text { Male }) \\
\text { Mean }( \pm \text { SD })\end{array}$ & $\mathrm{P}$ value \\
\hline$\overline{\text { Age (years) }}$ & $3.90(1.68)$ & $3.87(1.06)$ & \\
\hline Cobalt (nmol/L) & $3.03(1.85)$ & $2.36(0.81)$ & $0.07 *$ \\
\hline Chromium (nmol/L) & $25.68(12.10)$ & $21.15(13.31)$ & 0.15 \\
\hline Copper (umol/L) & $14.38(1.39)$ & $14.90(2.29)$ & 0.22 \\
\hline Magnesium (mmol/L) & $2.16(0.21)$ & $2.22(0.2)$ & 0.2 \\
\hline Manganese $(\mathrm{nmol} / \mathrm{L})$ & $407.40(92.85)$ & $417.60(136.73)$ & 0.4 \\
\hline Molybdenum (nmol/L) & $12.62(9.93)$ & $6.27(1.42)$ & $0.01 * *$ \\
\hline Selenium (umol/L) & $3.12(0.54)$ & $3.67(0.38)$ & $0.0006^{* * *}$ \\
\hline Vanadium (nmol/L) & $2.07(1.23)$ & $1.62(0.59)$ & $0.08 *$ \\
\hline Zinc (umol/L) & $134.95(23.94)$ & 148.27 (17.09) & $0.08 *$ \\
\hline
\end{tabular}

London Health Sciences Trace Elements Laboratory, London, Ontario for analysis. Erythrocytes were digested with nitric acid and hydrogen peroxide, diluted with purified water and analyzed on an ICP-MS, an inductively coupled plasma mass spectometer (Finnigan MAT Element High Resolution). The raw data from the digested samples was compared to standards of known concentration for the elements to be measured, to give final concentrations. Blood reference controls with know values were also analyzed to verify the method.

Statistical analysis: Comparison of red-cell trace mineral levels between autistic and control children was carried using the Student's t test with significance set at 0.05 . Important trends were identified where statistical $\mathrm{p}$ values fell between 0.05 and 0.1 .

\section{RESULTS AND DISCUSSION}

Red-cell levels of trace minerals for children with and without autism are summarized in Table 1. The children with autism demonstrated significantly lower selenium levels and a trend toward lower zinc status. However, molybdenum levels were significantly higher for children with autism, who also demonstrated a trend toward higher cobalt and vanadium levels. There were no significant differences or trends in chromium, copper, manganese and magnesium levels.

The current study found lower red-cell selenium in children with autism versus age-matched controls $(p<0.001)$, consistent with an earlier report of lower red-cell selenium in children with autism ${ }^{[7]}$.

Selenium plays an important role in the redox reactions of metallothionein and glutathione ${ }^{[8,9]}$. Selenium counteracts the oxidative effects of various heavy metals by seqestering them in nontoxic complex, as in in brain ${ }^{[10]}$. Selenium is an essential component of the anti-oxidant selenoprotein, GSHPx. Thus, by diverse mechanisms, lower selenium status modulates oxidative stress, which is reportedly greater in autism ${ }^{[11-}$ 14].

Greater oxidative stress in autism manisfests as increased peroxidation of lipid biomolecules, measurable in red-cells ${ }^{[2]}$ and urine ${ }^{[15,16]}$. This specific biochemical end-point is particularly sensitive to selenium status. As referenced previously, even borderline selenium results in depressed GSHPx, which protects cells from lipid peroxidation. Experimental selenium deficiency increased lipid peroxide level $\mathrm{s}^{[17]}$ and children with lower red-cell selenium concentrations evidenced decreased lipid peroxidation products after supplementation with selenium ${ }^{[18]}$. Selenium deficiency potentiates lipid peroxidation by neurotoxins such as paraquat ${ }^{[19]}$.

Catalase, which shares with selenium-dependent GSHPx the role of protecting cells from lipoperoxidation, is lower in the red cells of children with autism ${ }^{[2]}$. Combined depression of selenium and catalase would be expected to potentiate greater lipoxidation in children with autism.

The study does not confirm an earlier report of significantly lower red-cell zinc in children with autism ${ }^{[7]}$. The data demonstrate only a statistical trend ( $p=0.08)$ towards lower red-cell zinc. Further studies with expanded numbers of subjects are desirable in order to clarify zinc status in autism, given the important role of zinc in preventing lipoxidation of biomolecules.

Low zinc status definitely associates with increased tissue, mitochondrial and cell membrane peroxidation ${ }^{[20,21]}$. In zinc deficiency, unchecked free radicals increase cleavage of copper from MT, with resultant lipid peroxidation and apoptosis ${ }^{[22]}$. Zinc complexes with phospholipids to block oxidation of fatty membranes ${ }^{[5,20]}$ and blocks peroxidation of polyunsaturated lipids unbound to membranes ${ }^{[23]}$. Zinc 
supplementation can reverse this process, decreasing lipid peroxides in both diabetic and elder human models ${ }^{[24,25]}$. It is undetermined whether zinc supplementation in subjects with low or borderline selenium and normal zinc levels enjoy reduction in lipoxidation.

While inadequate dietary intake is an obvious possible explanation for depressed red-cell concentrations, toxic influences--or oxidative stress itself--should not be discounted as modulaters of trace mineral levels. In fetal alcohol syndrome, for instance, excess free radical production increases demand for antioxidant enzyme production, resulting in a net deficit in selenium and zinc relative to requirements ${ }^{[26-28]}$.

Higher (double) red-cell molybdenum $(\mathrm{p}=0.01)$ is a tentative new finding, for which we find no immediate context in the autism literature.

\section{ACKNOWLEDGEMENTS}

The Autism Research Institute funded this study. The authors are independent health practitioners and researchers with no commercial affiliations, nor financial conflicts of interest.

\section{REFERENCES}

1. Cornish, E., 2002. Gluten and casein free diets in autism: a study of the effects on food choice and nutrition. J. Hum. Nutr. Dietet., 15: 261-269.

2. Zoroglu, S.S., F. Armutcu, S. Ozen, A Gurel, E. Sivasli, O. Yetkin and I. Meram, 2004. Increased oxidative stress and altered activities of erythrocyte free radical scavenging enzymes in autism. Eur. Arch. Psychiatry. Clin. Neurosci., 254: 143-147.

3. Golse, B., P. Debray-Ritzen, P. Durosay, K. Puget and A.M. Michelson, 1978. Perturbation de deux enzymes; la superoxide-dismutaseI et la glutathione-peroxydase dans la psychose infantile de developpement (autisme infantile). Rev. Neurol., 134: 699-705.

4. Yorbik, O., A. Sayal, C. Akay, D.I. Akbiyik and T Sohmen, 2002. Investigation of antioxidant enzymes in children with autistic disorder. Prostaglandins, Leukotrienes and Essential Fatty Acids, 67: 341-343.

5. Ruz, M., K.R. Cavan, W.J. Bettger, P.W. Fischer and R.S. Gibson, 1992. Indices of iron and copper status during experimentally induced, marginal zinc deficiency in humans. Biol. Trace Elem. Res., 34: 197-212.
6. Isaacson, H.R., M.M. Moran and A. Hall, 1992. Autism: a retrospective outcome study of nutrient therapy. J. Appl. Nutr., 48: 110-118.

7. Audhya, T. and W. McGinnis, 2004. Nutrient, toxin and enzyme profile of autistic children. International Meeting for Autism Research (IMFAR), Sacramento CA, May 7-8, pp: 74.

8. Chen, Y. and W. Maret, 2001. Catalytic selenols couple the redox cycles of metallothionein and glutathione. Eur. J. Biochem., 268: 3346-3353.

9. Holben, D.H. and A.M. Smith, 1999. The diverse role of selenium within selenoproteins: A review. J. Am. Diet Assoc., 99: 836-843.

10. Whanger, P.D., 2001. Selenium and the brain: a review. Nutr. Neurosci., 4: 81-97.

11. McGinnis, W.R., 2004. Oxidative stress in autism. Alt. Thera. Hlth. Med., 10: 22-37.

12. Chauhan, A. and V. Chauhan, 2006. Oxidative stress in autism. Pathophysiology, 13: 171-181.

13. Kern, J.K. and A.M. Jones, 2006. Evidence of toxicity, oxidative stress and neuronal insult in autism. J. Toxicol. Environ. Hlth., 9: 485-99.

14. James, S.J., S. Melnyk, S. Jernigan, M.A. Cleves, C.H. Halsted, D.H. Wong, P. Cutler, K. Bock, M. Boris, J.J. Bradstreet, S.M. Baker and D.W. Gaylor, 2006. Metabolic endophenotype and related genotypes are associated with oxidative stress in children with autism. Am. J. Med. Genet. B Neuropsychiatr. Genet., 141: 947-956.

15. Ming, X., T.P. Stein, M. Brimacombe, W.H. Johnson, G.H. Lambert and G.C. Wagner, 2005. Prostaglandins Leukot Essent Fatty Acids, 73: 379384.

16. Yao, Y., W.J. Walsh, W.R. McGinnis and D Pratico, 2006. Altered vascular phenotype in autism: correlation with oxidative stress. Arch. Neurol., 63: 1161-1164.

17. Vanderlelie, J., K. Venardos and A.V. Perkins, 2004. Selenium deficiency as a model of experimental pre-eclampsia in rats. Reproduction, 128: 635-41.

18. Wilke, B.C., M. Vidailet and A. Favier et al., 1992. Selenium, glutathione peroxidase (GSH-Px) and lipid peroxidation products before and after selenium supplementation. Clin. Chim. Acta, 207: 137-42.

19. Glass, M., M.W. Sutherland and H.J. Forman et al. Selenium deficiency potentiates paraquat-induced lipid peroxidation in isolated perfused rat lung, 59: 619-22.

20. Cunnane, S.C., 1988. Role of zinc in lipid and fatty acid metabolism and in membranes. Prog. Food Nutr. Sci., 12: 151-188. 
21. Powell, S.R., 2000. The antioxidant properties of zinc. J. Nutr., 130: 1447S-1454S.

22. Liu, A, K. Kawai, V.A. Tyurin, Y.Y. Tyurina, G.G. Borisenko, J.P. Fabisiak, P.J. Quinn, B.R. Pitt and V.E. Kagan, 2001. Nitric oxide-dependent prooxidant and pro-apoptotic effect of metallothioneins in HL-60 cells challenged with cupric nitrilotriacetate. Biochem. J., 354: 397-406.

23. Peterson, D.A., J.M. Gerrard, J. Peller, G.H. Rao and J.G. White, 1981. Interactions of zinc and arachadonic acid. Prostaglandins Med., 6: 91-99.

24. Faure, P., P.Y. Benhamou, A. Perard, S. Halimi and A.M. Roussel, 1995. Lipid peroxidation in insulin-dependent diabetic patients with early retina degenerative lesions: effects of an oral zinc supplementation. Eur. J. Clin. Nutr., 49: 282-288.
25. Fortes, C., N. Agabiti, V. Fano, R. Pacifici, F. Forastiere, F. Virgili, P. Zuccaro, C.A. Perruci and S. Ebrahim, 1997. Zinc supplementation and plasma lipid peroxides in an elderly population. Eur. J. Clin. Nutr., 51: 97-101.

26. Mendelson, R.A. and A.M. Huber, 1979. The effect of ethanol consumption on trace elements in the fetal rat. Curr. Alcohol, 7: 39-48.

27. Zidenberg-Cherr, S., P.A. Benak, L.S. Hurley and C.L. Keen, 1988. Altered mineral metabolism: a mechanism underlying the fetal alcohol syndrome in rats. Drug Nutr. Interact., 5: 257-274.

28. Dreosti, I.E., 1984. Interactions between trace elements and alcohol in rats. Ciba Found Symp., 105: 103-123. 